NBER WORKING PAPER SERIES

\title{
ALLOCATING TIME: \\ INDIVIDUALS' TECHNOLOGIES, HOUSEHOLD TECHNOLOGY, PERFECT SUBSTITUTES, AND SPECIALIZATION
}

\author{
Robert A. Pollak \\ Working Paper 17529 \\ http://www.nber.org/papers/w17529
NATIONAL BUREAU OF ECONOMIC RESEARCH
1050 Massachusetts Avenue
Cambridge, MA 02138 \\ October 2011
}

This is the first of two theoretical papers on household time allocation; the second paper, Pollak (2012), discusses the conditions, other than perfect substitutes, under which efficiency implies specialization. Preliminary versions of this paper were presented at the PAA in New York, SOLE in Chicago, IZA in Bonn, ESPE in Chicago, the AEA in New Orleans, the University of Missouri, Duke University, Collegio Carlo Alberto in Torino, the University of Cergy-Pontoise, the University of Chicago, Mount Holyoke College, Cornell, UCLA, and the University of Maryland conference on International Perspectives on Time Use. I am grateful to Paula England, Shelly Lundberg, Mark Rosenzweig, Leslie Stratton, Yoram Weiss, and Randy Wright for conversations and comments, to Massimo Marinacci and Luigi Montrucchio for help proving a crucial result, and to two anonymous referees for their perceptive comments. I am grateful to the Eunice Kennedy Shriver National Institute of Child Health \& Human Development, National Institutes of Health (RO1HD056207-01A2) for financial support. I alone am responsible for the views expressed. The views expressed herein are those of the author and do not necessarily reflect the views of the National Bureau of Economic Research.

NBER working papers are circulated for discussion and comment purposes. They have not been peerreviewed or been subject to the review by the NBER Board of Directors that accompanies official NBER publications.

(C) 2011 by Robert A. Pollak. All rights reserved. Short sections of text, not to exceed two paragraphs, may be quoted without explicit permission provided that full credit, including $(\mathbb{C}$ notice, is given to the source. 
Allocating Time: Individuals' Technologies, Household Technology, Perfect Substitutes, and Specialization

Robert A. Pollak

NBER Working Paper No. 17529

October 2011, Revised April 2012

JEL No. D13,J22

\begin{abstract}
In an efficient household if the spouses' time inputs are perfect substitutes, then spouses will "specialize" regardless of their preferences and the governance structure. That is, both spouses will not allocate time to both household production and the market sector. The perfect substitutes assumption implies that spouses' "unilateral" production functions (i.e., the household production function when only one spouse allocates time to home production) are closely related, satisfying a highly restrictive condition that I call "compatibility."

I introduce the "correspondence assumption," which postulates that the unilateral production functions in a newly formed household coincide with individuals' production functions before they enter marriage. The correspondence assumption provides a plausible account of the genesis of household technology and simplifies its estimation. I introduce the "additivity assumption" which postulates that the household production function is the sum of the spouses' unilateral production functions and argue that additivity is implicit in much of the new home economics. Together, the correspondence and additivity assumptions imply that individuals' technologies reveal the entire household technology.
\end{abstract}

I show that perfect substitutes, additivity and concavity imply that the household production function is of the same form as the unilateral production functions, exhibits constant returns to scale, and depends on the spouses' total time inputs, measured in efficiency units.

\author{
Robert A. Pollak \\ Washington University in St. Louis \\ Arts and Sciences \\ and the Olin Business School \\ Campus Box 1133 \\ 1 Brookings Drive \\ St. Louis, MO 63130-4899 \\ and NBER \\ pollak@wustl.edu
}




\section{Introduction}

The household production model remains the lens through which virtually all economists and many other social scientists view household time allocation. For many social scientists, certainly for economists, the starting point of the modern time-use literature is Becker (1965), "A Theory of the Allocation of Time." In that paper, Becker introduced the household production model which has become the centerpiece of what Nerlove (1974) called the "new home economics."1 Becker's 1965 article placed household time allocation on the agenda of economics and, directly and indirectly, profoundly influenced time use studies in the other social sciences.

Becker (1965) provided a clear statement of the foundations of the household production model in the context of a single-person household. Becker wrote: "Households will be assumed to combine time and market goods to produce more basic commodities that directly enter their utility functions." ${ }^{2}$ Becker (1965) barely mentioned families or multiple-person households, devoting only a single paragraph to "The Division of Labour Within Families." ${ }^{3}$

\footnotetext{
${ }^{1}$ Of course there were precursors -- most immediately Mincer (1963) and, three decades earlier, Reid (1934), Economics of Household Production, a book whose title suggests its concerns.

${ }^{2}$ The household production model includes the traditional neoclassical model as a special case Proof: Suppose that there are $\mathrm{n}$ goods and $\mathrm{n}$ commodities, and that the household production functions are such that one unit of good i produces one unit of commodity $i$; this corresponds to a degenerate household technology in which commodities are produced by market goods without any input of household time. The utility function defined over commodities thus becomes a utility function defined over market goods. Hence, without additional assumptions about technology and/or preferences, the new home economics places no additional restrictions on labor supply functions or on the demand functions for market goods. ${ }^{3}$ The distinction between household and family is generally ignored in the literature on households and families and I continue in this venerable tradition. The difficulty is suggested by such phrases as "household production," which often refers to family production, and by "traditional nuclear family" and "stem family," which refer to types of households. The growing literature on coresidence and proximity, for example, Pezzin, Pollak, and Schone (2007), and Compton and Pollak (2009), recognizes that who lives with whom and who lives near whom are endogenous.
} 
In retrospect, the most important contribution of the new home economics has been to draw attention to the nonmarket behavior of households and, especially, to behavior within households. In addition to time allocation, examples include investments in health, investments in children's human capital, and fertility. When "A Theory of the Allocation of Time" appeared in 1965, "revealed preference" rhetoric held sway in economics and economists equated "observable behavior" with "market behavior." Hence, most economists recognized only two uses of time: market work ("labor"), observable because it passed through a market, and a residual consisting of all other uses of time misleadingly called "leisure."

Issues of time allocation and division of labor arise in all multiple-person households: married couples, cohabiting heterosexual couples, gay and lesbian couples, multigenerational households in which adult children coreside with disabled elderly parents, and nonfamily households (e.g., roommates or housemates). ${ }^{5}$ I focus on heterosexual married couples, both for definiteness and because they have been the major focus of time use research. With some qualifications, however, the analysis also applies to cohabiting couples regardless of their sexual orientation or marital status and, more generally, to all multiple-person households. To the extent that marriage and cohabitation differ (e.g., in cost of exit and degree of commitment), the same preferences and household production technologies may generate different patterns of time allocation. In the short run, such differences are presumably attributable to differences in transaction

\footnotetext{
${ }^{4}$ Commuting fits awkwardly into this dichotomous classification.

${ }^{5}$ As the title of Becker's chapter "Division of Labor in Households and Families" suggests, specialization implicates families as well as households. Of course family formation and the sorting of individuals into households is endogenous. Ellickson (2008) provides an insightful discussion of complex households.
} 
costs and commitment. In the long run, these differences may be amplified by differences in human capital investments. ${ }^{6}$

For economists, the household production model refocused the discussion of time use away from the labor/leisure choice and toward the allocation of productive nonmarket time. This refocusing requires at least a trichotomous classification of time use (market work/ household production/ leisure) and, for some purposes, a fine-grained classification of activities within the household. Unlike the labor economics literature on equalizing differentials with its emphasis on the pleasantness or unpleasantness of various occupations, the new home economics typically assumed the absence of "process preferences." That is, individuals derive no "direct utility" (Pollak and Wachter, 1975), "psychic benefits" or "process benefits" (Juster and Stafford, 1991) from various household activities (e.g., cooking vs cleaning). ${ }^{7}$ Instead, the new home economics assumed that individuals were indifferent between market work and household work and, when it recognized more than one household production activity, indifferent among these activities as well. Labor economists, familiar with Adam Smith's analysis of occupational choice and equalizing wage differentials, should have insisted on an analogous analysis of nonmarket time. Such an analysis of the allocation of time among productive household activities would recognize a role for process preferences. But although it might seem a small step from recognizing differences in the pleasantness of

\footnotetext{
${ }^{6}$ To analyze choice of marital status and its implications for time allocation requires both a multiperiod framework and an analysis of the marriage / cohabitation markets, both of which are beyond the scope of this paper. A substantial literature in sociology analyzes the differences in time use patterns in married couple and cohabiting couple households. Whether we attribute these differences to differences in household technology or to transaction cost and commitment issues is primarily a semantic rather than an analytical question.

${ }^{7}$ I prefer the term "process preferences" because it more easily accommodates the possibility that these effects are negative (i.e., "disbenefits") rather than positive.
} 
various categories of market work to recognizing differences in the pleasantness of various categories of household work, it is a step that few economists took.

Since the mid 1980s, virtually all research on time use has been empirical rather than theoretical. The most recent theoretical work cited in most time use papers is the 1991 edition of Becker's Treatise on the Family. The 1991 date suggests that the theoretical work is more recent than it actually is: all of the time use analysis in the Treatise had been published previously. The first of the three time use chapters, "SinglePerson Households," which appeared in the 1981 edition of the Treatise, generalized the household production model of Becker (1965) by introducing sector-specific human capital that augments the productivity of time in household production. ${ }^{8}$ The second of these chapters, the "Division of Labor in Households and Families," which also appeared in the 1981 edition of the Treatise, presented the celebrated "specialization theorems," concluding that efficiency requires specialization. Becker's analysis of specialization generally assumes two "sectors," "market" and "household," and concludes that, in an efficient household, both spouses do not allocate time to both sectors. The third time use chapter, originally published as Becker (1985), elaborates the earlier discussion of the "sexual division of labor" and examines the allocation of "effort."

"Specialization" has a precise meaning in economic theory, one that differs from its often imprecise meaning in ordinary language. In ordinary language, we might say there is specialization when husbands spend substantially more time than wives in market

\footnotetext{
${ }^{8}$ Becker (1965) did not discuss the role of human capital in household production. The assumption that the type of human capital that increases productivity in home production differs from the type of human capital that increases productivity in the market plays an important role in Becker's discussion of specialization. The importance of specialized human capital in household production is an important open question.

${ }^{9}$ The empirical time use literature in economics has done little to analyze the allocation of effort, surely a missed opportunity. If we assume that effort corresponds to unpleasantness, then effort would provide a back door for introducing process preferences into the analysis.
} 
work and wives spend substantially more time than husbands in household work. In economic theory, we say there is specialization if and only if both spouses do not allocate time to both the market sector and the household sector (i.e., if both spouses allocate time to both sectors, then there is nonspecialization). The definition of specialization in terms of the overlap in spouses' patterns of time use is consistent with standard usage in the economics of the family and analogous to definitions familiar from Ricardian models of international trade.

In addition to the claim that efficiency implies specialization, Becker argues that the efficient pattern of specialization is gendered. Specifically, if both husbands and wives work in the market sector, then only wives work in the household sector. And if both husbands and wives work in the household sector, then only husbands work in the market sector. In this paper my concern is with the claim that efficiency implies specialization, not with the further claim about gender. If the specialization claim fails, as I believe it does, then the further claim about the gendering of specialization is moot.

The analysis of multiple-person households involves three basic elements or primitives: (1) the preferences of individual household members, (2) constraints and opportunities, including not only resource and time constraints and the household technology, but also the technologies of individual household members; and (3) the household "governance structure" (e.g., the altruist model; cooperative Nash bargaining) that determines the mapping from preferences and constraints (including household and individuals' technologies) into allocations of time, purchases of market goods, production of commodities, and their allocation among individuals in the household. ${ }^{10}$

${ }^{10}$ Randy Wright correctly points out that information structure is an additional basic element. To avoid dealing with information structure, I assume full information although some important topics in the 
1. Preferences. Individuals' preferences specify the objective functions that individuals seek to maximize. If one spouse has all the bargaining power, then that spouse would maximize his or her own individual utility, subject to technology and other constraints, recognizing that the other spouse will divorce rather than accept an allocation that is worse than his or her outside option. In order to focus on other issues, I assume the absence of "altruism" and other forms of interdependent preferences (e.g., preferences in which one spouse cares about the utility, consumption, or time use of the other). ${ }^{11}$

\section{Constraints (including household and individuals' technologies).}

Household technology specifies the constraints, other than the market and time constraints, that define a household's feasible set. Household technology can be represented by production sets or, in the absence of joint production, by production functions. ${ }^{12}$ Individuals' technologies specify the constraints, other than the market and time constraints, that individuals would face if they were living alone rather than in a multiple-person household. Individuals' technologies are required to analyze individuals' decisions to enter or leave marriage, a point that has received virtually no attention in the literature on marriage and divorce. ${ }^{13}$ In virtually all bargaining models, divorce is an

economics of the family clearly depend on less than full information. These include "shirking," extra marital affairs, and transaction costs. A satisfactory treatment of information structure awaits the further development of dynamic bargaining models that recognize asymmetric information.

${ }^{11}$ The introduction to the 1991 edition of the Treatise acknowledges that the specification of interdependent preferences that Becker calls "altruism" is overly restrictive because it excludes "merit goods," which he concedes are a plausible type of interdependence preferences. The literature on bargaining in marriage generally assumes away altruism.

${ }^{12}$ Pollak and Wachter (1975) show that when process preferences are associated with household production activities, the household technology involves joint production. The three chapters on time use in Becker's Treatise assume away joint production and, hence, process preferences.

${ }^{13}$ Analogously, to analyze adolescents' and young adults' decisions to leave their parents' households requires us to specify individuals' technologies. 
"outside option" that determines the set of mutually acceptable allocations. In some bargaining models (e.g., in Nash bargaining models where the threat point is divorce), individuals' well-being in the event of divorce is the sole determinant of their bargaining power in marriage. Both the household production and family bargaining literatures have ignored individuals' technologies and the relationship between individuals' technologies and household technology.

3. Governance structure. The household governance structure determines the mapping from individuals' preferences and constraints (including household and individuals' technologies) into allocations. The phrase "governance structure" is broad enough to include not only cooperative and noncooperative bargaining models, but also Becker's altruist model and, indeed, any model that determines the sharing of benefits and burdens in a multiple-person household. ${ }^{14}{ }^{15}$ Because they restrict their attention to singleperson households, Becker (1965) and Pollak and Wachter (1975) rely on utility maximization. In the Treatise, Becker considers multiple-person

\footnotetext{
${ }^{14}$ The phrase "governance structure" is borrowed from the transaction cost literature; see, for example Williamson (2002). Transaction costs -- the costs of negotiating, monitoring, and enforcing agreements -can be treated as a component of household governance structure, although an argument can be made for treating transaction costs as a separate element in the analysis of multiple-person households. A rigorous treatment of transaction cost issues requires a specification of information structure and a model of dynamic bargaining with asymmetric information. The application of transaction cost analysis to the household began with Ben-Porath (1980) and Pollak (1985). Ellickson (2006) provides an insightful transaction cost analysis of household size, composition, and governance, emphasizing the importance of norms rather than legally-enforceable obligations. Pollak (2007) relates Ellickson's analysis to the literature on household and family bargaining. The sharing rule of Chiappori's collective model can be interpreted as a reduced form corresponding to an unspecified household governance structure that yields Pareto-efficient allocations; see Chiappori $(1988,1992)$.

15 My focus in this paper is on household technology, not on governance structures. The altruist model is susceptible to strong theoretical and empirical objections described in Lundberg and Pollak (1996). The theoretical competitors are bargaining models, which come in many varieties, some of which include the altruist model as a special case.
} 
households, but restricts his attention to those that maximize household utility functions subject to household technology, budget, and time constraints. $\mathrm{He}$ justifies this restriction by appealing to the altruist model which implies that multiple-person households behave as if they were single-person households (i.e., they maximize a household utility function -- the utility function of the altruist -- subject to appropriate household constraints). Models implying household behavior that is consistent with maximizing a household utility function subject to household constraints are called unitary models. Unitary models imply that household members "pool" their resources, so that lump sum transfers (e.g., of nonlabor income) from one spouse to the other have no effect on household behavior. Resource pooling is a testable implication of unitary models, an implication that is consistently rejected by empirical data; Lundberg and Pollak (2008) summarize the evidence. Any analysis that assumes or implies that households maximize a household utility function subject to appropriate household constraints is inconsistent with this empirical evidence and ignores the bargaining concerns that now play a central role in the economics of the family. ${ }^{16}$

This basic three-element framework -- preferences, constraints (including household and individuals' technologies), and the governance structure -- clarifies the role of technology as a determinant of the division of labor within households. It should

\footnotetext{
${ }^{16}$ Divorce threat bargaining models of marriage were introduced in the early 1980 s by Manser and Brown (1980) and by McElroy and Horney (1981). Lundberg and Pollak (1993) introduced the "separate spheres" bargaining model and, in Lundberg and Pollak (1994), a noncooperative household bargaining model. A decade and a half before the first household bargaining models, Samuelson (1956) pointed out that unitary models, which often begin by postulating rather than deriving a household utility function, fail to address
} 
be no surprise that, except in very special cases, conclusions about the allocation of time depend on assumptions about preferences and governance structure as well as technology. The assumption that spouses' time inputs into household production are perfect substitutes is the leading example of a special case in which an assumption about technology by itself leads to strong conclusions about time allocation.

Since the 1950s the time use patterns of married men and married women have been converging, and theoretical predications that husbands specialize in market work and wives specialize in household work are inconsistent with empirical findings. Lundberg and Pollak (2007) summarize the evidence and provide references to the literature showing that husbands and wives participate in both the home and the market sectors. In the 2005 American Time Use Survey, married women reported an average of 16 hours per week of 'household activities' compared to a bit less than 11 hours for men. Data from the Current Population Survey (CPS) show that the labor force participation rate of married women between 25 and 44 years of age is greater than 70 percent, while the rate of married men in this age group is 95 percent. Thus, the prediction of sector specialization is inconsistent with data on time use patterns in the early 21 st century.

After introducing notation for technology in single person households (section 2), I introduce the "correspondence assumption" which postulates a relationship between individuals' technologies and household technology (section 3). More specifically, the correspondence assumption postulates that individuals' technologies for producing a commodity coincide with the "unilateral" household technology for producing that commodity (i.e., the household technology when only one spouse allocates time to its

\footnotetext{
the problem of aggregating individuals' preferences into household preferences; Pollak (2006) discusses Samuelson's contribution and its relationship to subsequent work.
} 
production). Specialization in household production implies a crucial role for the unilateral technologies.

The relationship between household technology and individuals' technologies is especially interesting because it is potentially observable at two crucial transition points: household formation and divorce. ${ }^{17}$ At the point of household formation, the technologies of individuals before they form a new household are related to the technology of the newly-formed household. At the point of divorce, the technology of the household prior to divorce is related to the technologies of the newly-divorced individuals.

I then introduce the "additivity assumption," which postulates that household technology is the sum of the spouses' unilateral technologies. I argue that many discussions of household production implicitly assume additivity. Taken together, the correspondence assumption and the additivity assumption imply that individuals' technologies are the atoms from which household technology is constructed.

I then discuss the meaning of specialization (section 4). I define specialization in terms of the overlap in spouses' patterns of time use. More specifically, the household pattern of time use is specialized if there is at most one activity to which both spouses allocate time. That is, we have "bilateral production" of a commodity (i.e., production when both spouses allocate time to its production) for at most one commodity and unilateral production of all other commodities.

\footnotetext{
${ }^{17}$ When a spouse dies, the household's technology prior to the death and any commodity-specific human capital that the surviving spouse acquired prior to or during the marriage will determine his or her technology as a widow or widower. Anecdotes about widowers who cannot cook and widows who have never made financial decisions and find themselves confronted by a host of unfamiliar problems exemplify the difficulties that (over)specialization can imply for surviving spouses. The disability of a spouse raises related issues. The nondisabled spouse must either find market substitutes or take over household
} 
I then consider household technologies in which spouses' time inputs are "perfect substitutes" (section 5). I show that the perfect substitutes assumption implies that spouses unilateral technologies satisfy a highly restrictive condition that I call "compatibility." I show that if spouses' time inputs are perfect substitutes, then the spouses in an efficient household will specialize: regardless of how many commodities are produced within an efficient household, there is at most one commodity to which both spouses allocate time.

I next consider the implications of imposing both the additivity assumption and the perfect substitutes assumption (section 6). I show that if household technology satisifies additivity, perfect substitutes and concavity, then the household technology exhibits constant returns to scale. Section 7 summarizes and concludes.

\section{Household Production in Single-Person Households}

I begin with single-person households, introducing notation and terminology. For a single-person household, I denote the production function for commodity $\mathrm{z}_{\mathrm{i}}$ by

$$
\mathrm{z}_{\mathrm{i}}=\mathrm{f}^{\mathrm{i}}\left(\mathrm{t}_{\mathrm{i}}, \mathrm{y}_{\mathrm{i}}\right)
$$

where $t_{i}$ denotes the input of household time ("labor") into its production and $y_{i}$ the vector of market goods used as inputs. ${ }^{18}$ Focusing on a particular commodity, z, and dropping the identifying commodity superscripts and subscripts, we write

$$
z=f(t, y)
$$

production activities previously performed by the now-disabled spouse. Disability, however, also raises new issues including disability insurance and family and nonfamily caregiving.

${ }^{18}$ Alternatively, $\mathrm{y}_{\mathrm{i}}$ may be interpreted as the total cost of the market inputs used to produce $\mathrm{z}_{\mathrm{i}}$. This total cost or expenditure interpretation, which takes the prices of the market goods as given, has the advantage of reducing $\mathrm{y}_{\mathrm{i}}$ from a vector to a scalar. The corresponding disadvantage is having prices appear in the "production function." 
Hired labor (e.g., for cleaning the house or caring for the children) may be one of the market goods. Henceforth I use "labor" to mean household time inputs and "hired labor" to mean nonhousehold time inputs. I assume that hired labor requires monitoring and supervision and, therefore, is not a perfect substitute for household labor. ${ }^{19}$

I treat market work as an additional household production activity. In the simplest case, the technology is linear: earnings are equal to the product of the wage rate and hours worked. The story becomes more complicated if there are nonlinear taxes, premia for overtime, or fixed costs associated with working. It is also more complicated if we recognize that inputs of market goods affect wages through what Becker (1965) calls "productive consumption." My default assumption, however, is that earnings are proportional to hours of market work.

Technology in one adult household, especially the technology for producing children with high levels of cognitive and noncognitive skills, will play an important role in shaping the workforce on the 21st century. As Lundberg and Pollak (2007) point out, the fraction of children under age 18 who live with only one parent rose from 9 percent in 1960 to 28 percent in 2005 . Thus, the technology of single parent families would deserve attention even if it shed no light on technology of married couple households.

In both theoretical and empirical work, economists often assume that production functions exhibit constant returns to scale:

$$
\mathrm{f}(\lambda \mathrm{t}, \lambda \mathrm{y})=\lambda \mathrm{f}(\mathrm{t}, \mathrm{y}) \quad \text { for all } \lambda>0 .
$$

When time is the only input, constant returns to scale implies

\footnotetext{
${ }^{19}$ There is, of course, a substantial literature on monitoring and supervision in firms and in farm households. The "servant problem," monitoring and supervising hired workers within domestic households, although prominent 19th century novels and diaries, has received little attention from economists, except in
} 


$$
\mathrm{f}(\mathrm{t})=\mathrm{ct}
$$

I say that an individual's time input into the production of a particular commodity is essential if

$$
f(0, y)=0
$$

If an individual's time input is essential, then $\mathrm{t}=0$ implies $\mathrm{z}=0$ regardless of the quantities of the nonlabor inputs.

\section{Household Technology and Individuals' Technologies: The Correspondence}

\section{Assumption and the Additivity Assumption}

The new home economics has thus far not analyzed the relationship between individuals' production functions and household production functions. After introducing notation for production functions in multiple person households, I introduce the correspondence assumption and the additivity assumption. The correspondence assumption postulates a relationship between the individuals' production functions and the unilateral production functions of the household technology. The additivity asssumption postulates that the household production function is the sum of the spouses' unilateral production functions. The additvity assumption implies that bilateral production entails spouses' producing side-by-side, each spouses using his or her unilateral production function.

Becker's discussion of specialization in the Treatise generally assumes that there are only two sectors, "market" and "home," each of which is treated as a single activity. In this two-sector case, "strong specialization" means that one spouse works in the home 
and not in the market, and the other spouse works in the market but not in the home. "Specialization" (i.e., "weak specialization") means that one spouse allocates time to a single sector (either home or market), while the other spouse may allocate time to one sector or to both sectors. The widespread pattern in which both spouses allocate time to both market work and household work corresponds to "nonspecialization."

I begin by introducing notation and terminology for married-couple households. Dropping the commodity superscripts and subscripts, I denote the household production function for $z$ by $g\left[t_{1}, t_{2}, y\right]$, where $t_{1}$ and $t_{2}$ denote the spouses' time inputs into the production of z. For each commodity produced within the household, either both spouses allocate time to its production ("bilateral production") or only one spouse allocates time to its production ("unilateral production"). For commodities produced unilaterally, the relevant domain of the household production function consists of the values at which $t_{1}=$ 0 or $\mathrm{t}_{2}=0$. I call $\mathrm{g}\left[\mathrm{t}_{1}, 0, \mathrm{y}\right]$ and $\mathrm{g}\left[0, \mathrm{t}_{2}, \mathrm{y}\right]$ the spouses' unilateral production functions.

The correspondence assumption relates household technology to the technologies of individuals (e.g., before they enter marriage). The new home economics postulates the existence of household production functions, but is silent about their genesis. In addition to providing at least a partial account of the origin of household technology, the correspondence assumption has implications for empirical work. In both single person and multiple person households, estimation of technology is difficult because the allocation of time is endogenous. The estimation of technologies (e.g., for child outcomes) is simpler in single person households than in multiple person household because time allocation in one person households is much simpler than time allocation in multiple person households. This is true even of the estimation of spouses' unilateral 
technologies in multiple person households. The complication is that in multiple person households, time allocation (e.g., to invest in a child's human capital) depends not only on the entire household technology, but also on the preferences of both spouses and the governance structure. In a single person household, time allocation depends only on that individual's technology and his or her preferences. There is no need to consider the technology or preferences of anyone else and, because there is no need to coordinate behavior or resolve conflicts, there is no governance structure. ${ }^{20}$

The Correspondence Assumption postulates a simple, plausible relationship between the spouses' individual production functions, $\left\{\mathrm{f}^{1}\left(\mathrm{t}_{1}, \mathrm{y}_{1}\right), \mathrm{f}^{2}\left(\mathrm{t}_{2}, \mathrm{y}_{2}\right)\right\}$, and the unilateral household production functions, $\left\{\mathrm{g}\left[\mathrm{t}_{1}, 0, \mathrm{y}\right], \mathrm{g}\left[0, \mathrm{t}_{2}, \mathrm{y}\right]\right\}$.

Correspondence Assumption: The unilateral household production functions at time $\tau,\left\{\mathrm{g}\left[\mathrm{t}_{1}, 0, \mathrm{y} ; \tau\right], \mathrm{g}\left[0, \mathrm{t}_{2}, \mathrm{y} ; \tau\right]\right\}$, coincide with the individuals' production functions at time $\tau,\left\{\mathrm{f}^{1}\left(\mathrm{t}_{1}, \mathrm{y} ; \tau\right), \mathrm{f}^{2}\left(\mathrm{t}_{2}, \mathrm{y} ; \tau\right)\right\}$ :

$$
\mathrm{g}\left[\mathrm{t}_{1}, 0, \mathrm{y} ; \tau\right]=\mathrm{f}^{1}\left(\mathrm{t}_{1}, \mathrm{y} ; \tau\right)
$$

and

$$
\mathrm{g}\left[0, \mathrm{t}_{2}, \mathrm{y} ; \tau\right]=\mathrm{f}^{2}\left(\mathrm{t}_{2}, \mathrm{y} ; \tau\right) .
$$

Explicitly including $\tau$ in the household and individuals' production functions serves as a reminder that both household and individuals' technologies may change over time (e.g., as the result of technical progress or investment in human capital). Desirable though such a reminder would be, hereafter I omit $\tau$ to avoid notational clutter.

The individuals' production functions, $\left\{\mathrm{f}^{1}\left(\mathrm{t}_{1}, \mathrm{y}_{1}\right), \mathrm{f}^{2}\left(\mathrm{t}_{2}, \mathrm{y}_{2}\right)\right\}$, may be interpreted as those of prospective spouses, and $g\left[t_{1}, t_{2}, y\right]$ as the production function of the household

\footnotetext{
${ }^{20}$ This is an exaggeration: there may be bargaining with family members outside the household. For example, a lone mother often must coordinate with and resolve conflicts with the child's father and with her
} 
they form as a married couple. An alternative interpretation is that individuals' production functions are those of former spouses immediately after their divorce and $g\left[t_{1}, t_{2}, y\right]$ is the production function of their household immediately before divorce The difficulty with the divorce interpretation is that household production by couples on the verge of divorce may be inefficient because of the spouses' failure to cooperate or coordinate. ${ }^{21}$

The correspondence assumption implies that

- if we know individuals' production functions, $\left\{\mathrm{f}^{1}\left(\mathrm{t}_{1}, \mathrm{y}_{1}\right), \mathrm{f}^{2}\left(\mathrm{t}_{2}, \mathrm{y}_{2}\right)\right\}$, we can infer the portions of the household production function corresponding to unilateral production, $\left\{\mathrm{g}\left[\mathrm{t}_{1}, 0, \mathrm{y}\right], \mathrm{g}\left[0, \mathrm{t}_{2}, \mathrm{y}\right]\right\}$, and

- if we know the portions of the household production functions corresponding to unilateral production, $\left\{\mathrm{g}\left[\mathrm{t}_{1}, 0, \mathrm{y}\right], \mathrm{g}\left[0, \mathrm{t}_{2}, \mathrm{y}\right]\right\}$, we can infer the individuals' production functions, $\left\{\mathrm{f}^{1}\left(\mathrm{t}_{1}, \mathrm{y}_{1}\right), \mathrm{f}^{2}\left(\mathrm{t}_{2}, \mathrm{y}_{2}\right)\right\}$.

Without additional assumptions, the link between household technology and individuals' technologies postulated by the correspondence assumption is useful only if unilateral production is prevalent. If we accept Becker's specialization theorems, which conclude that efficiency implies unilateral production in two-earner households, then we would expect pervasive unilateral production. ${ }^{22}$

The "additivity assumption," implies that the spouses' unilateral production

own parents.

${ }^{21}$ A third interpretation is that individuals' production functions are those of a surviving spouse. A difficulty with the surviving spouse interpretation is that if the surviving spouse was providing care for the deceased spouse, then the commodities produced by the married couple household may be very different from the commodities produced by the surviving spouse.

${ }^{22}$ For a critique of Becker's specialization theorems, see Folbre (2004), Lundberg (2008), and Pollak (2012). 
functions are the atoms from which the household technology is built. Specifically, the additivity assumption postulates that total output is the sum of the outputs the spouses would produce unilaterally when nonlabor inputs are allocated between them so as to maximize total output. With the additivity assumption, bilateral production involves spouses producing "side-by-side," each spouse using his or her unilateral technology. Thus, the additivity assumption enables us to construct simple, tractable examples and counterexamples.

Formally,

Additivity Assumption: The household technology is of the form

$$
\begin{aligned}
& \mathrm{g}\left[\mathrm{t}_{1}, \mathrm{t}_{2}, \mathrm{y}\right]=\max \left\{\mathrm{g}^{1}\left(\mathrm{t}_{1}, 0, \mathrm{y}_{1}\right)+\mathrm{g}^{2}\left(0, \mathrm{t}_{2}, \mathrm{y}_{2}\right)\right\} \\
& \text { subject to } \mathrm{y}_{1}+\mathrm{y}_{2} \leq \mathrm{y} .
\end{aligned}
$$

Much of the new home economics, including much of Becker's analysis of specialization in Chapter 2 of the Treatise, implicitly assumes that household technology satisfies the additivity assumption. Unfortunately, the additivity assumption is not plausible in the household context, where it has neither theoretical nor empirical support. The additivity assumption was plausible in the context of late 18th and early 19th century international trade, where it plays a central role in the Ricardian model of comparative advantage. Indeed, the Ricardian model provides a useful lens through which to view Becker's analysis of time allocation and specialization in multiple-person households.

Together, the correspondence assumption and the additivity assumption provide a complete account of the origin of the household technology. Thus, if we impose both the correspondence assumpton and the additivity assumption, individuals' production 
functions identify the entire household production function. Thus, the additivity assumption greatly amplifies the power of the correspondence assumption.

Imposing both the correspondence assumption and the additivity assumption, we can rewrite the household production function in terms of individuals' production functions as:

$$
\mathrm{g}\left[\mathrm{t}_{1}, \mathrm{t}_{2}, \mathrm{y}\right]=\max \left\{\mathrm{f}^{\mathrm{l}}\left(\mathrm{t}_{1}, \mathrm{y}_{1}\right)+\mathrm{f}^{2}\left(\mathrm{t}_{2}, \mathrm{y}_{2}\right)\right\}
$$

subject to $\mathrm{y}_{1}+\mathrm{y}_{2} \leq \mathrm{y}$.

When there are no nonlabor inputs, this simplifies to

$$
g\left[t_{1}, t_{2}\right]=f^{1}\left(t_{1}\right)+f^{2}\left(t_{2}\right) .
$$

The separability assumption generalizes the additivity assumption by allowing the production by one spouse to interfere with or reinforces the productivity of the other. If we take additivity as the starting point, we can interpret the separability assumption as allowing a limited class of "within household externalties."

Formally,

Separability Assumption: The household technology is of the form

$$
\mathrm{g}\left[\mathrm{t}_{1}, \mathrm{t}_{2}, \mathrm{y}\right]=\max \Omega\left[\mathrm{g}^{1}\left(\mathrm{t}_{1}, 0, \mathrm{y}_{1}\right), \mathrm{g}^{2}\left(0, \mathrm{t}_{2}, \mathrm{y}_{2}\right)\right]
$$

subject to $\mathrm{y}_{1}+\mathrm{y}_{2} \leq \mathrm{y}$.

Unlike additivity, separability allows positive and negative "externalities" or "spillovers" within the household, but these effects operate only through the unilateral production functions. If we impose the correspondence assumption, we can rewrite the separability assumption in terms of individuals' production functions as:

$$
\mathrm{g}\left[\mathrm{t}_{1}, \mathrm{t}_{2}, \mathrm{y}\right]=\max \Omega\left[\mathrm{f}^{1}\left(\mathrm{t}_{1}, \mathrm{y}_{1}\right), \mathrm{f}^{2}\left(\mathrm{t}_{2}, \mathrm{y}_{2}\right)\right]
$$

subject to $\mathrm{y}_{1}+\mathrm{y}_{2} \leq \mathrm{y}$. 
When there are no nonlabor inputs, this simplifies to

$$
g\left[t_{1}, t_{2},\right]=\Omega\left[f^{1}\left(t_{1}\right), f^{2}\left(t_{2}\right)\right]
$$

\section{The Meaning of Specialization}

The distinction between bilateral and unilateral production leads directly to a general definition of specialization. On the basis of the household's time allocation, we partition the commodities into three subsets: commodities produced bilaterally, commodities produced unilaterally, and commodities not produced within the household. To discuss gender specialization requires distinguishing between unilateral production by the husband and unilateral production by the wife. Becker argues both that efficiency implies specialization and that the efficient pattern of specialization is gendered, with husbands working in the market sector and wives working in the household sector. My concern is with the claim that efficiency implies specialization; if this specialization claim fails, then the further claim about the gendering of specialization becomes moot.

\section{Definition:}

1. Nonspecialization: For at least one pair of activities/commodities, both spouses allocate time to both (i.e., the set of commodities produced bilaterally is at least a doubleton).

2. Specialization: For every pair of activities/commodities, at most one spouse allocates time to both (i.e., the set of commodities produced bilaterally is either empty or a singleton).

3. Strong specialization: For every activity/commodity, no more than one spouse allocates time to its production (i.e., the set of commodities produced bilaterally is empty). ${ }^{23}$

\footnotetext{
23 "Strong specialization" might be called "complete" or "full" specialization; in contrast, "specialization" might be called "weak," "incomplete," or "partial" specialization.
} 
Three features of the time-overlap definition of specialization deserve comment. First, the definition places no restriction on the number of activities/commodities other than the requirement that there are at least two. ${ }^{24}$ Second, a list of activities/commodities is a prerequisite for defining unilateral and bilateral production. Narrower specifications of activities will result in a greater fraction of unilateral activities, but economic theory provides little guidance for specifying activities. For example, suppose that wives and only wives cook indoors, and that husbands and only husbands cook outdoors. If cooking indoors and cooking outdoors are treated as a single activity (i.e., "cooking"), then "cooking" is a bilateral activity. If "cooking indoors" and "cooking outdoors" are treated as two separate activities, then each is a unilateral activity. An appeal to production cannot resolve whether cooking indoors and cooking outdoors are one activity or two. Third, despite the rhetoric of household production, the listed household activities need not correspond to recognizable production activities. Because specialization is defined in terms of the overlap in spouses' patterns of time use, data on spouses' time use and a list of time use activities are the only prerequisites to assessing whether there is specialization.

\section{Perfect Substitutes and Specialization}

The new home economics postulates that the listed time use activities correspond to household production functions, and that these household production functions satisfy certain assumptions. Assumptions about household technology, together with the postulated correspondence, enable us to derive conclusions about efficient patterns of household time allocation.

${ }^{24}$ When there are exactly two activities (e.g., home and market), these definitions reduce to Becker's. 
The new home economics sometimes assumes that time inputs of husbands and wives are perfect substitutes. Becker (1991, p. 32) uses the perfect substitutes assumption to motivate his discussion of specialization in multiple-person households, although his specialization theorems do not assume that spouses' time inputs are perfect substitutes.

Perfect Substitutes Assumption: Husband's time and wife's time are perfect substitutes if the household production function can be written as

$$
\mathrm{g}\left[\mathrm{t}_{1}, \mathrm{t}_{2}, \mathrm{y}\right]=\mathrm{G}\left[\mathrm{t}_{1}+\alpha(\mathrm{y}) \mathrm{t}_{2}, \mathrm{y}\right]
$$

where the "efficiency factor," $\alpha(y)$, converts the time input of spouse 2 into units comparable with the time input of spouse 1.

Thus, $\mathrm{t}_{1}+\alpha(\mathrm{y}) \mathrm{t}_{2}$ represents the total time input into the production of the commodity z, measured in the "efficiency units" relevant to producing commodity $\mathrm{z}$ : $1 / \alpha(y)$ hours of the time of spouse 2 is equivalent to one hour of the time of spouse 1 in the production of commodity z. The perfect substitutes assumption implies that isoquants in the $\left(t_{1}, t_{2}\right)$ space are linear, although their slopes may depend on the vector of nonlabor inputs, $\mathrm{y}$. And, of course, efficiency factors may differ from one commodity to another.

If spouses' time inputs are perfect substitutes and if output is produced by time alone (i.e., if there are no nonlabor inputs), then $\alpha(y)$ is a constant and

$$
\mathrm{g}\left[\mathrm{t}_{1}, \mathrm{t}_{2}\right]=\mathrm{G}\left[\mathrm{t}_{1}+\alpha \mathrm{t}_{2}\right]
$$

If spouses' time inputs are perfect substitutes and the household production function is homothetic, then $\alpha(y)$ is homogeneous of degree 0 . (Proof: If the production function is homothetic, then all marginal rates of technical substitution are homogeneous of degree 0 . The marginal rate of substitution of $t_{2}$ for $t_{1}$ is equal to $\alpha(y)$. Hence, $\alpha(y)$ must be 
homogeneous of degree 0.) When the household production function is homothetic and there is only one nonlabor input, then $\alpha(y)$ is a constant. (Proof: The only function of one variable that is homogeneous of degree 0 is a constant.) If the relative prices of nonlabor inputs are fixed, then there is effectively only one nonlabor input (i.e., the Hicksian composite commodity measured by expenditure on the nonlabor inputs) and $\alpha(y)$ is a constant. Unfortunately, there is less to this result than meets the eye: we are merely replacing efficiency factors that depend on the vector of nonlabor input quantities with efficiency factors that depend on the vector of nonlabor input prices.

The perfect substitutes assumption implies that spouses' unilateral production functions are "compatible" in the following sense:

Definition: The unilateral production functions corresponding to a household production function $\mathrm{g}\left[\mathrm{t}_{1}, \mathrm{t}_{2}, \mathrm{y}\right]$ are "compatible" if there exists a function $\mathrm{G}[. .$,$] . and a$ function $\alpha(y)$ such that

$$
\begin{aligned}
& \mathrm{g}\left[\mathrm{t}_{1}, 0, \mathrm{y}\right]=\mathrm{G}\left[\mathrm{t}_{1}, \mathrm{y}\right] \text { and } \\
& \mathrm{g}\left[0, \mathrm{t}_{2}, \mathrm{y}\right]=\mathrm{G}\left[\alpha(\mathrm{y}) \mathrm{t}_{2}, \mathrm{y}\right]
\end{aligned}
$$

Theorem: The perfect substitutes assumption implies that the spouses' unilateral production functions are compatible.

Proof: The prefect substitutes assumption implies that the household production function is of the form

$$
\mathrm{g}\left[\mathrm{t}_{1}, \mathrm{t}_{2}, \mathrm{y}\right]=\mathrm{G}\left[\mathrm{t}_{1}+\alpha(\mathrm{y}) \mathrm{t}_{2}, \mathrm{y}\right]
$$

so

$$
\begin{aligned}
& \mathrm{g}\left[\mathrm{t}_{1}, 0, \mathrm{y}\right]=\mathrm{G}\left[\mathrm{t}_{1}, \mathrm{y}\right] \\
& \mathrm{g}\left[0, \mathrm{t}_{2}, \mathrm{y}\right]=\mathrm{G}\left[\alpha(\mathrm{y}) \mathrm{t}_{2}, \mathrm{y}\right]
\end{aligned}
$$


If $\alpha(y)$ is a constant, compatibility reduces to

$$
\begin{aligned}
& \mathrm{g}\left[\mathrm{t}_{1}, 0, \mathrm{y}\right]=\mathrm{G}\left[\mathrm{t}_{1}, \mathrm{y}\right] \\
& \mathrm{g}\left[0, \mathrm{t}_{2}, \mathrm{y}\right]=\mathrm{G}\left[\alpha \mathrm{t}_{2}, \mathrm{y}\right]
\end{aligned}
$$

That is, the spouses' unilateral production functions differ only in a single parameter.

Corollary: The correspondence assumption and the perfect substitutes assumption imply that the spouses' individual production functions are compatible.

Taken together, the correspondence assumption and the perfect substitutes assumption imply that prospective spouses enter marriage with compatible individual technologies. This strong restriction on the relationship between the individual technologies of men and women entering marriage is an immediate implication of the correspondence assumption and the perfect substitutes assumption. I can think of only two circumstances, neither very plausible, that would ensure that household unilateral production functions and spouses' individual production functions satisfy this restriction. First, the individual production functions of all prospective spouses (i.e., everyone in the marriage market) might be compatible. Second, immediately after each marriage, one spouse might adopt the technology of the other (e.g., the more productive spouse might successfully teach his or her technology to the less productive spouse), a within household version of "technology transfer." 25

Perfect substitutes imply specialization or, more precisely, perfect substitutes and production efficiency imply specialization. Because perfect substitutes imply linear isoquants (in a subspace), this is hardly surprising. To formalize the argument requires notation for two activities. If there are more than two activities, the argument establishes

\footnotetext{
25 The technology transfer hypothesis implies that immediately after divorce, the individual production functions of the former spouses are compatible.
} 
that, in an efficient household, there is no pair of activities to which both spouses allocate time. Becker's discussion considers a market sector and a household sector rather than two household activities. We can, however, interpret the market sector as a household production activity in which the spouses' marginal products (i.e., their wage rates) are constant. In the obvious notation, we write

$$
\begin{aligned}
& \mathrm{g}^{1}\left[\mathrm{t}_{\mathrm{h} 1}, \mathrm{t}_{\mathrm{w} 1}, \mathrm{y}_{1}\right]=\mathrm{G}^{1}\left[\mathrm{t}_{\mathrm{h} 1}+\alpha_{1} \mathrm{t}_{\mathrm{w} 1}, \mathrm{y}_{1}\right]=\mathrm{G}^{1}\left[\mathrm{t}_{1}, \mathrm{y}_{1}\right] \\
& \mathrm{g}^{2}\left[\mathrm{t}_{\mathrm{h} 2}, \mathrm{t}_{\mathrm{w} 2}, \mathrm{y}_{2}\right]=\mathrm{G}^{2}\left[\mathrm{t}_{\mathrm{h} 2}+\alpha_{2} \mathrm{t}_{\mathrm{w} 2}, \mathrm{y}_{2}\right]=\mathrm{G}^{2}\left[\mathrm{t}_{2}, \mathrm{y}_{2}\right] .
\end{aligned}
$$

The notation I use in the remainder of this section differs from that used elsewhere in this paper. Although gender plays no role in this paper, a gender-neutral notation using numerical double subscripts (spouse 1; spouse 2; activity 1; activity 2) would be less transparent than using $\mathrm{h}$ for husband and $\mathrm{w}$ for wife.

A proof by contradiction is straightforward. Consider any efficient time allocation that involves bilateral production. Holding $\mathrm{y}_{1}$ and $\mathrm{y}_{2}$ fixed, I show that it is possible to reallocate labor between the two activities in a way that increases the output in one activity without decreasing output in the other. More precisely, such a reallocation is possible provided $\alpha_{2} \neq \alpha_{1}$; in the razor's edge case in which $\alpha_{2}=\alpha_{1}$, nonspecialization (i.e., bilateral production of both commodities) as well as specialization is efficient. Assuming $\alpha_{2} \neq \alpha_{1}$, with no loss of generality, I designate the activities so that $\alpha_{2}>\alpha_{1}$.

The argument traces through the consequences of reducing the wife's time allocation to the production of commodity 1 by $\Delta$ and increasing the husband's time allocation to the production of commodity 1 by $\alpha_{1} \Delta$. This maintains output of commodity 1 at its original level because $t_{h 1}$ and $t_{\mathrm{w} 1}$ are perfect substitutes and one hour of the wife's time is equivalent to $\alpha_{1}$ hours of the husband's time in the production of 
commodity 1 . We now examine the consequences for the time allocated to commodity 2 and their implications for output of commodity 2 . That is, the wife's time input to commodity 2 increases by $\Delta$ (which increases the time inputs in efficiency units by $\alpha_{2} \Delta$ ), and the husband's time input into commodity 2 decreases by $\alpha_{1} \Delta$ (which decreases the time input in efficiency units by $\alpha_{1} \Delta$ ). The net effect on time inputs into the production of commodity 2 in efficiency units is $\alpha_{2} \Delta-\alpha_{1} \Delta=\left(\alpha_{2}-\alpha_{1}\right) \Delta$, which is positive because $\alpha_{2}>$ $\alpha_{1}$. Hence, the net result of this reallocation of time is that output of commodity 1 is unchanged, while output of commodity 2 increases, contradicting our assumption that the initial time allocation was efficient.

Unlike many proofs by contradiction, this argument is transparent. Provided $\alpha_{2} \neq$ $\alpha_{1}$ and starting from any initial time allocation with bilateral production, we can increase output by transferring time inputs from one commodity to the other. We can continue these time transfers until one of the four time input variables, $\left\{\mathrm{t}_{\mathrm{h} 1}, \mathrm{t}_{\mathrm{h} 2}, \mathrm{t}_{\mathrm{w} 1}, \mathrm{t}_{\mathrm{w} 2}\right\}$, reaches 0 , at which point we have specialization.

\section{Additivity, Perfect Substitutes, and Constant Returns to Scale}

In this section I show that essentiality, additivity, perfect substitutes, and concavity imply constant returns to scale. ${ }^{26}$ More specifically, the household production function is of the same form as the underlying unilateral production function and depends on the total time inputs, measured in efficiency units. Formally,

Theorem 1: Suppose that the household production function is defined for all $\mathrm{t}, 0 \leq \mathrm{t} \leq \mathrm{T}$, and satisfies the essentiality, additivity, perfect substitutes, and concavity assumptions. Then $G[t, y]$ is homogeneous of degree 1 in the sense that : 


$$
\mathrm{G}(\lambda \mathrm{t}, \lambda \mathrm{y})=\lambda \mathrm{G}(\mathrm{t}, \mathrm{y}) \quad \text { for all } \lambda>0 \text { for which } \lambda \mathrm{t} \leq \mathrm{T} .^{27}
$$

I begin with a theorem characterizing the household technologies consistent with additivity, perfect substitutes, and constant returns to scale.

Theorem 2: Suppose that the household production function satisfies the additivity and perfect substitutes assumptions, and that spouses have constant returns to scale unilateral production functions. That is,

$$
\mathrm{g}\left[\mathrm{t}_{1}, \mathrm{t}_{2}, \mathrm{y}\right]=\max \mathrm{G}\left[\mathrm{t}_{1}, \mathrm{y}_{11}, \ldots, \mathrm{y}_{1 \mathrm{n}}\right]+\mathrm{G}\left[\alpha(\mathrm{y}) \mathrm{t}_{2}, \alpha(\mathrm{y}) \mathrm{y}_{21}, \ldots, \alpha(\mathrm{y}) \mathrm{y}_{2 \mathrm{n}}\right]
$$

subject to the constraints

$$
\mathrm{y}_{1 \mathrm{i}}+\mathrm{y}_{2 \mathrm{i}}=\mathrm{y}_{\mathrm{i}}, \quad \mathrm{i}=1, \ldots . \mathrm{n},
$$

where $\mathrm{G}[\mathrm{t}, \mathrm{y}]$ is homogeneous of degree 1 and $\alpha(\mathrm{y})$ is homogeneous of degree 0 .

Then the household production function is given by

$$
\mathrm{g}\left[\mathrm{t}_{1}, \mathrm{t}_{2}, \mathrm{y}\right]=\mathrm{G}\left[\mathrm{t}_{1}+\alpha(\mathrm{y}) \mathrm{t}_{2}, \mathrm{y}_{1}, \ldots, \mathrm{y}_{\mathrm{n}}\right] .
$$

To motivate both the results and the proof, consider the case in which spouses have identical unilateral production functions. With additivity the household production function $\mathrm{g}\left[\mathrm{t}_{1}, \mathrm{t}_{2}, \mathrm{y}\right]$ is given by

$$
\mathrm{g}\left[\mathrm{t}_{1}, \mathrm{t}_{2}, \mathrm{y}\right]=\max \mathrm{G}\left[\mathrm{t}_{1}, \mathrm{y}_{11}, \ldots, \mathrm{y}_{1 \mathrm{n}}\right]+\mathrm{G}\left[\mathrm{t}_{2}, \mathrm{y}_{21}, \ldots, \mathrm{y}_{2 \mathrm{n}}\right]
$$

subject to the constraints

$$
\mathrm{y}_{1 \mathrm{i}}+\mathrm{y}_{2 \mathrm{i}}=\mathrm{y}_{\mathrm{i}}, \quad \mathrm{i}=1, \ldots ., \mathrm{n} .
$$

The first order conditions are

$$
\mathrm{G}_{1 \mathrm{i}}\left[\mathrm{t}_{1}, \mathrm{y}_{11}, \ldots, \mathrm{y}_{1 \mathrm{n}}\right]=\mu
$$

${ }^{26}$ Essentiality is the assumption for the unilateral production function: a time input of 0 implies 0 output.

${ }^{27}$ The domain is restricted because there are only 24 hours in a day. 


$$
\mathrm{G}_{2 \mathrm{i}}\left[\mathrm{t}_{2}, \mathrm{y}_{21}, \ldots, \mathrm{y}_{2 \mathrm{n}}\right]=\mu \text {. }
$$

Because the function $G[t, y]$ is homogeneous of degree 1, its partial derivatives are homogenous of degree 0 . Hence, the first order conditions imply

$$
\mathrm{y}_{1 \mathrm{i}} / \mathrm{t}_{1}=\mathrm{y}_{2 \mathrm{i}} / \mathrm{t}_{2}=\left(\mathrm{y}_{\mathrm{i}}-\mathrm{y}_{1 \mathrm{i}}\right) / \mathrm{t}_{2} \quad \mathrm{i}=1, \ldots, \mathrm{n} .
$$

Solving for $\mathrm{y}_{1 \mathrm{i}}$ and $\mathrm{y}_{2 \mathrm{i}}$ yields

$$
\mathrm{y}_{1 \mathrm{i}}=\mathrm{t}_{1} \mathrm{y}_{\mathrm{i}} / \mathrm{T} \text { and } \mathrm{y}_{2 \mathrm{i}}=\mathrm{t}_{2} \mathrm{y}_{\mathrm{i}} / \mathrm{T}
$$

where

$$
\mathrm{T}=\mathrm{t}_{1}+\mathrm{t}_{2}
$$

Substituting for $\mathrm{y}_{1 \mathrm{i}}$ and $\mathrm{y}_{2 \mathrm{i}}$ in the household production function yields

$$
\begin{aligned}
& g\left[t_{1}, t_{2}, y\right]=G\left[t_{1}, t_{1} y_{1} / T, \ldots, t_{1} y_{n} / T\right]+G\left[t_{2}, t_{2} y_{1} / T, \ldots, t_{2} y_{n} / T\right]= \\
& =\mathrm{t}_{1} \mathrm{G}\left[1, \mathrm{y}_{1} / \mathrm{T}, \ldots, \mathrm{y}_{\mathrm{n}} / \mathrm{T}\right]+\mathrm{t}_{2} \mathrm{G}\left[1, \mathrm{y}_{1} / \mathrm{T}, \ldots, \mathrm{y}_{\mathrm{n}} / \mathrm{T}\right]= \\
& \mathrm{T} \mathrm{G}\left[1, \mathrm{y}_{1} / \mathrm{T}, \ldots, \mathrm{y}_{\mathrm{n}} / \mathrm{T}\right]= \\
& \mathrm{G}\left[\mathrm{T}, \mathrm{y}_{1}, \ldots, \mathrm{y}_{\mathrm{n}}\right]=\mathrm{G}\left[\mathrm{t}_{1}+\mathrm{t}_{2}, \mathrm{y}_{1}, \ldots, \mathrm{y}_{\mathrm{n}}\right]
\end{aligned}
$$

Unlike the example, which assumes that the spouses have identical unilateral production functions, the theorem assumes that the spouses' time inputs are perfect substitutes, which implies that their unilateral production functions are "compatible" in the sense that

$$
\begin{aligned}
& \mathrm{g}\left[\mathrm{t}_{1}, 0, \mathrm{y}\right]=\mathrm{G}\left[\mathrm{t}_{1}, \mathrm{y}\right] \text { and } \\
& \mathrm{g}\left[0, \mathrm{t}_{2}, \mathrm{y}\right]=\mathrm{G}\left[\alpha(\mathrm{y}) \mathrm{t}_{2}, \mathrm{y}\right]
\end{aligned}
$$

Thus, the example corresponds to the case in which $\alpha(y)=1$.

Proof of Theorem 2: The argument used in the example applies directly to the case in which $\alpha$ is constant -- instead of factoring out $t_{2}$, we factor out $\alpha t_{2}$. At first sight, the case in which $\alpha(y)$ is not constant seems more complicated because it appears that we must 
deal with the partial derivatives of $\alpha(y)$ with respect to $y_{1 i}, y_{2 i}$ etc. Fortunately, this is not the case. Because $\alpha(y)$ depends only on the sum $y_{i}=y_{1 i}+y_{2 i}$, these derivatives of $\alpha(y)$ are 0 so the first order conditions imply

$$
\mathrm{y}_{1 \mathrm{i}} / \mathrm{t}_{1}=\mathrm{y}_{2 \mathrm{i}} / \alpha(\mathrm{y}) \mathrm{t}_{2}=\left(\mathrm{y}_{\mathrm{i}}-\mathrm{y}_{1 \mathrm{ii}}\right) / \alpha(\mathrm{y}) \mathrm{t}_{2} \quad \mathrm{i}=1, \ldots ., \mathrm{n} .
$$

Solving for $\mathrm{y}_{1 \mathrm{i}}$ and $\mathrm{y}_{2 \mathrm{i}}$ yields

$$
\mathrm{y}_{1 \mathrm{i}}=\mathrm{t}_{1} \mathrm{y}_{\mathrm{i}} / \mathrm{T} \text { and } \mathrm{y}_{2 \mathrm{i}}=\alpha(\mathrm{y}) \mathrm{t}_{2} \mathrm{y}_{\mathrm{i}} / \mathrm{T} \text {, }
$$

where

$$
\mathrm{T}=\mathrm{t}_{1}+\alpha(\mathrm{y}) \mathrm{t}_{2} .
$$

I next show that essentiality, additivity, perfect substitutes, and concavity imply constant returns to scale. To motivate the result and the proof, I begin with the case in which output is produced by household time alone. I show that in this case each spouse's output is proportional to his or her time input. (When time is the only input, we do not need to assume concavity.) That is,

$$
\begin{aligned}
& \mathrm{g}\left[\mathrm{t}_{1}, 0\right]=\mathrm{ct} \mathrm{t}_{1} \\
& \mathrm{~g}\left[0, \mathrm{t}_{2}\right]=\mathrm{c} \alpha \mathrm{t}_{2}
\end{aligned}
$$

and

$$
\mathrm{g}\left[\mathrm{t}_{1}, \mathrm{t}_{2}\right]=\mathrm{G}\left[\mathrm{t}_{1}+\alpha \mathrm{t}_{2}\right]=\mathrm{c}\left(\mathrm{t}_{1}+\alpha \mathrm{t}_{2}\right)
$$

where $\alpha$ is a constant (because there are no nonlabor inputs). Hence, under the stated conditions, $g\left[t_{1}, t_{2}\right]$ is homogeneous of degree 1 . The conclusion that the household production function is homogeneous of degree 1 generalizes to the case in which there are nonlabor inputs.

When time is the only input, the proof is straightforward. Combining the additivity and perfect substitutes assumptions implies: 


$$
\mathrm{g}\left[\mathrm{t}_{1}, \mathrm{t}_{2}\right]=\mathrm{G}\left[\mathrm{t}_{1}+\alpha \mathrm{t}_{2}\right]=\mathrm{g}\left[\mathrm{t}_{1}, 0\right]+\mathrm{g}\left[0, \mathrm{t}_{2}\right]
$$

Making use of the assumption that individuals' time inputs are essential, we obtain

$$
\begin{aligned}
& \mathrm{G}\left[\mathrm{t}_{1}\right]=\mathrm{g}\left[\mathrm{t}_{1}, 0\right] \\
& \mathrm{G}\left[\alpha \mathrm{t}_{2}\right]=\mathrm{g}\left[0, \mathrm{t}_{2}\right]
\end{aligned}
$$

so

$$
\mathrm{G}\left[\mathrm{t}_{1}+\alpha \mathrm{t}_{2}\right]=\mathrm{G}\left[\mathrm{t}_{1}\right]+\mathrm{G}\left[\alpha \mathrm{t}_{2}\right]^{28}
$$

Differentiating with respect to $t_{1}$ yields

$$
\mathrm{G}^{\prime}\left[\mathrm{t}_{1}+\alpha \mathrm{t}_{2}\right]=\mathrm{G}^{\prime}\left[\mathrm{t}_{1}\right]
$$

Because $t_{2}$ appears on the left hand side but not on the right hand side, the function $G^{\prime}[]$ must be constant (i.e., independent of $t_{1}$ and $t_{2}$ ). Hence, the function G[ ] must be linear in $\mathrm{t}$

$$
\mathrm{G}[\mathrm{t}]=\mathrm{b}+\mathrm{ct}^{29}
$$

Again using the assumption that individuals' time inputs are essential, we conclude that the constant term, $b$, must be 0 . Hence

$$
\mathrm{G}[\mathrm{t}]=\mathrm{ct}
$$

so

$$
\begin{aligned}
& \mathrm{g}\left[\mathrm{t}_{1}, 0\right]=\mathrm{ct}_{1} \\
& \mathrm{~g}\left[0, \mathrm{t}_{2}\right]=\mathrm{c} \alpha \mathrm{t}_{2}
\end{aligned}
$$

and

$$
\mathrm{G}\left[\mathrm{t}_{1}+\alpha \mathrm{t}_{2}\right]=\mathrm{c}\left(\mathrm{t}_{1}+\alpha \mathrm{t}_{2}\right)
$$

${ }^{28}$ This is Cauchy's functional equation (see Aczél and Dhombres, 1989).

${ }^{29}$ Although the argument in the text depends on differentiability, the result does not. 
Lemma: Suppose that the household production function is defined for all $\mathrm{t}, 0 \leq \mathrm{t}$ $\leq \mathrm{T}$, and satisfies the essentiality, additivity, perfect substitutes, and concavity assumptions. Then

$$
\mathrm{G}[2 \mathrm{t}, 2 \mathrm{y}]=2 \mathrm{G}[\mathrm{t}, \mathrm{y}]
$$

Remark: The Lemma does not assert that $G[t, y]$ is homogeneous of degree 1 . To show that $G[t, y]$ is homogeneous of degree 1 requires an additional argument, although not additional assumptions.

Proof of Lemma: Combining the additivity and perfect substitutes assumptions implies

$$
\mathrm{G}\left[\mathrm{t}_{1}+\alpha(\mathrm{y}) \mathrm{t}_{2}, \mathrm{y}\right]=\mathrm{G}\left[\mathrm{t}_{1}, \mathrm{y}_{1}\right]+\mathrm{G}\left[\alpha(\mathrm{y}) \mathrm{t}_{2}, \mathrm{y}_{2}\right]
$$

where $\mathrm{y}$ is allocated between $\mathrm{y}_{1}$ and $\mathrm{y}_{2}$ to maximize output. Treating $\mathrm{y}$ as fixed, let $\mathrm{t}_{2}=$ $\mathrm{t}_{1} / \alpha(\mathrm{y})$ so

$\mathrm{G}\left[\mathrm{t}_{1}+\alpha(\mathrm{y}) \mathrm{t}_{2}, \mathrm{y}\right]=\mathrm{G}\left[\mathrm{t}_{1}+\mathrm{t}_{1}, \mathrm{y}\right]=\mathrm{G}\left[\mathrm{t}_{1}, \mathrm{y}_{1}\right]+\mathrm{G}\left[\mathrm{t}_{1}, \mathrm{y}_{2}\right]=2 \mathrm{G}\left[\mathrm{t}_{1}, \mathrm{y} / 2\right]$

(The last equality follows from the concavity of $G[$,$] ; when t_{2}=t_{1} / \alpha(y)$, allocating y to maximize output implies $\left.y_{1}=y_{2}=y / 2\right)$. Hence

$$
\mathrm{G}\left[\mathrm{t}_{1}+\mathrm{t}_{1}, \mathrm{y}\right]=\mathrm{G}\left[2 \mathrm{t}_{1}, \mathrm{y}\right]=2 \mathrm{G}\left[\mathrm{t}_{1}, \mathrm{y} / 2\right] \text {. }
$$

Define $\mathrm{t}=\mathrm{t}_{1}$ and $\mathrm{y}^{*}=\mathrm{y} / 2$. Then

$$
\mathrm{G}\left[2 \mathrm{t}, 2 \mathrm{y}^{*}\right]=2 \mathrm{G}\left[\mathrm{t}, \mathrm{y}^{*}\right]
$$

\section{Proof of Theorem 1: ${ }^{30}$}

We define the function $\mathrm{H}(\lambda)$ by

$$
\mathrm{H}(\lambda)=\mathrm{G}(\lambda \mathrm{t}, \lambda \mathrm{y})-\lambda \mathrm{G}(\mathrm{t}, \mathrm{y}) \text { for all } \lambda \geq 0 .
$$

To show that $\mathrm{G}(\mathrm{t}, \mathrm{y})$ is homogeneous of degree 1 is equivalent to showing that $H(\lambda)=0$ for all admissible $\lambda$. 
From the definition of $\mathrm{H}(\lambda)$

$$
\begin{aligned}
& H(0)=0 \\
& H(1)=0 \\
& H(2)=0 .
\end{aligned}
$$

We show that the concavity of G(t,y) implies the concavity of $H(t, y)$, and that the only concave function for which $\mathrm{H}(0)=\mathrm{H}(1)=\mathrm{H}(2)=0$ is homogeneous of degree 1. The essential idea of the proof is that, because the function $\mathrm{H}(\mathrm{t}, \mathrm{y})$ is concave, if the function has a negative first derivative at any point, then its first derivative must remain negative once the function turns down, it can never turn up.

The concavity of $G(t, y)$ implies

$$
H^{\prime \prime}(\lambda) \leq 0 \text {. }
$$

Hence, $H^{\prime}(\lambda)$, the first derivative of the function $H(\lambda)$, must be constant or decreasing. We focus on $\mathrm{H}^{\prime}(0)$, the right hand derivative of $\mathrm{H}()$ at $\lambda=0$. There are three cases.

Case I. $\mathrm{H}^{\prime}(0)<0$. In this case, the function $\mathrm{H}(\lambda)$ is negative for all admissible values of $\lambda$ sufficiently close to 0 . Hence, if $H(\lambda)$ is to satisfy $H(1)=0$, the function $H(\lambda)$ must increase somewhere on $(0,1)$. But $\mathrm{H}(\lambda)$ can never increase because $\mathrm{H}^{\prime}(0)<0$ and $\mathrm{H}^{\prime \prime}(\lambda) \leq$ 0 for all admissible $\lambda$. This rules out Case I.

Case II. $H^{\prime}(0)>0$. In this case, the function $H(\lambda)$ is positive for admissible values of $\lambda$ sufficiently close to 0 . Hence, if $H(\lambda)$ is to satisfy $H(1)=0$, the function $H(\lambda)$ must reach a maximum on $(0,1)$ and decrease to satisfy $\mathrm{H}(1)=1$. This implies $\mathrm{H}^{\prime}()<0$ somewhere on $(0,1)$ and, because $H^{\prime \prime}(\lambda) \leq 0$ for all admissible $\lambda$, this implies $H^{\prime}(1)<0$. In order to satisfy $\mathrm{H}(2)=0$, the function $\mathrm{H}(\mathrm{)})$ must increase somewhere on $(1,2)$, but this is impossible because $\mathrm{H}^{\prime}(1)<0$ and $\mathrm{H}^{\prime \prime}(\lambda) \leq 0$ for all admissible $\lambda$. This rules out Case II.

${ }^{30}$ Although the proof assumes that $\mathrm{H}$ is twice differentiable, the result holds under weaker assumptions. 
Case III. Hence, we are left with $H^{\prime}(0)=0$. We show that this is implies $H(\lambda)=0$ for all admissible $\lambda$. Because $H^{\prime \prime}(\lambda) \leq 0$ for all admissible $\lambda, H^{\prime}(0)=0$ implies $H^{\prime}(\lambda) \leq 0$ for all admissible $\lambda$. But if $\mathrm{H}^{\prime}\left(\lambda^{*}\right)<0$ for some $\lambda^{*}$, then we must have $\mathrm{H}(\lambda)<0$ for some $\lambda$ near $\lambda^{*}$. But this implies that $H()$ can never increase on $\left(\lambda^{*}, 2\right)$ as it must if it is to satisfy $\mathrm{H}(2)=0$

\section{Conclusion}

The analysis of time allocation in multiple person households requires three basic elements: preferences, constraints (including household and individuals' technologies), and the household governance structure. Except in special cases, each of these three basic elements plays a role in determining household time allocation. Perfect substitutes is such a special case. In an efficient household, regardless of preferences and the governance structure, if the spouses' time inputs are perfect substitutes, then spouses will "specialize." Specialization has a precise meaning in economics. In the economics of the family, when there are two sectors, home and market, we say there is specialization if and only if both spouses do not allocate time to both sectors. The usage and much of the analysis is borrowed from the Ricardian model of international trade. The perfect substitutes assumption leads directly to specialization. But the perfect substitutes assumption implies that spouses' unilateral production functions are closely related, satisfying a highly restrictive condition that I call "compatibility."

Individuals' technologies (e.g., the technologies of prospective spouses; the technologies of former spouses) deserve much more attention than they have thus far received. Individuals' technologies are required to analyze individuals' decisions to enter or leave marriage. Furthermore, if we impose the "correspondence assumption," which 
postulates that household "unilateral" production functions coincide with individuals' production functions, then individuals' technologies open a window onto household technology. The correspondence assumption also provides a plausible account of the genesis of household technology or, more precisely, of a portion of household technology. Taken together, the correspondence and perfect substitutes assumptions imply that the individual production functions of prospective spouses are compatible.

The "additivity assumption" postulates that the household production function is the sum of the spouses' unilateral production functions. Thus, the additivity assumption implies that spouses' unilateral production functions are a sufficient statistic for the entire household technology. With the additivity assumption, the spouses' unilateral technologies provide a very wide window into household technology: when we know the spouses' unilateral production functions, we can infer the entire household production function. If the household technology is concave and satisfies the perfect substitutes and additivity assumptions, then the household technology exhibits constant returns to scale.

These results suggest that the technologies of individuals (i.e., the technologies of one-adult households) deserve more attention. Individuals' technologies (e.g., for investing in children's cognitive and noncognitive skills) are interesting and important in their own right. Furthermore, individuals' technologies are far easier to estimate than the technologies of multiple person households for three reasons: because the individuals' technologies are simpler than household technology, because we need consider the preferences of only one individual, and because governance structures play no role in one-person households. If we accept the correspondence assumption and believe that unilateral production is common, then individuals' technologies provide important 
information about household technology. Indeed, if we accept the correspondence and additivity assumptions, then individuals' technologies reveal the entire household technology. 


\section{References:}

Aczél, J., and J. Dhombres, Functional Equations in Several Variables, Cambridge: Cambridge University Press, 1989.

Becker, Gary S., "A Theory of the Allocation of Time," Economic Journal, Vol. 75, No. 299, (September 1965), 493-517.

Becker, Gary S., "Human Capital, Effort, and the Sexual Division of Labor," Journal of Labor Economics, Vol. 3, No. 1, Pt. 2, (January 1985), S33-S58.

Becker, Gary S., A Treatise on the Family, Cambridge: Harvard University Press, 1981; Enlarged edition, 1991.

Ben-Porath, Yoram, "The F-Connection: Families, Friends, and Firms and the Organization of Exchange," Population and Development Review, Vol. 6, No. 1, (March 1980), 1-30.

Chiappori, Pierre-André, "Rational Household Labor Supply," Econometrica, Vol. 56, No. 1, (January 1988), 63-89.

Chiappori, Pierre-André, "Collective Labor Supply and Welfare," Journal of Political Economy, Vol. 100, No. 3, (June 1992), 437-467.

Compton, Janice and Robert A. Pollak, "Proximity and Coresidence of Adult Children to their Parents: Description and Correlates," University of Michigan Retirement Research Center, Working Paper 2009-215, October 2009.

Ellickson, Robert C., "Unpacking the Household: Informal Property Rights Around the Hearth," Yale Law Journal, Vol. 116, No. 2, (November 2006), 226-328.

Ellickson, Robert C., The Household: Informal Order around the Hearth, Princeton: Princeton University Press, 2008.

Folbre, Nancy, "'Holding Hands at Midnight': The Paradox of Caring Labor," Feminist Economics, Vol. 1, No. 1, (Spring 1995), 73-92.

Folbre, Nancy, "A Theory of the Misallocation of Time." In N. Folbre and M. Bittman, eds., Family Time: The Social Organization of Care, London: Routledge, 2004. 7-24.

Juster, F. Thomas and Frank P. Stafford, "The Allocation of Time: Empirical Findings, Behavioral Models, and Problems of Measurement," Journal of Economic Literature, Vol. 29, No. 2, (June 1991), 471-522. 
Lundberg, Shelly J., "Gender and Household Decision-Making." In F. Bettio and A. Verashchagina, eds., Frontiers in the Economics of Gender, New York: Routledge, 2008. 116-133.

Lundberg, Shelly and Robert A. Pollak, "Separate Spheres Bargaining and the Marriage Market," Journal of Political Economy, Vol. 101, No. 6, (December 1993), 988-1010.

Lundberg, Shelly and Robert A. Pollak, "Noncooperative Bargaining Models of Marriage," American Economic Review, Vol. 84, No. 2, (May 1994), 132-137.

Lundberg, Shelly and Robert A. Pollak, "Bargaining and Distribution in Marriage," Journal of Economic Perspectives, Vol. 10, No. 4, (Fall 1996), 139-158.

Lundberg, Shelly and Robert A. Pollak, "The American Family and Family Economics," Journal of Economic Perspectives, Vol. 21, No. 2, (Spring 2007), 3-26.

Lundberg, Shelly and Robert A. Pollak, "Family Decision-Making," The New Palgrave, Dictionary of Economics, 2nd Edition, Larry Blume and Steven Durlauf, eds. Palgrave Macmillan, 2008.

Manser, Marilyn and Murray Brown, "Marriage and Household Decision-Making: A Bargaining Analysis," International Economic Review, Vol. 21, No. 1, (February 1980), $31-44$.

McElroy, Marjorie B. and Mary J. Horney, "Nash-Bargained Household Decisions: Toward a Generalization of the Theory of Demand," International Economic Review, Vol. 22, No. 2, (June 1981), 333-349.

Mincer, Jacob, "Market Prices, Opportunity Costs, and Income Effects." In C. Christ et al., eds., Measurement in Economics: Studies in Mathematical Economics and Econometrics in Memory of Yehuda Grunfeld, Stanford: Stanford University Press, 1963. 67-82.

Nerlove, Marc, "Household and Economy: Toward a New Theory of Population and Economic Growth," Journal of Political Economy, Vol. 83, No.2, Part II, (March/April 1974), S200-S218.

Pezzin, Liliana, Robert A. Pollak, and Barbara S. Schone, "Efficiency in Family Bargaining: Living Arrangements and Caregiving Decisions of Adult Children and Disabled Elderly Parents," CESifo Economic Studies, Vol. 53, No. 1, (March 2007), 69-96.

Pollak, Robert A., "A Transaction Cost Approach to Families and Households," Journal of Economic Literature, Vol. 23, No. 2 (June 1985), 581-608.

Pollak, Robert A., "Gary Becker's Contributions to Family and Household Economics," Review of Economics of the Household, Vol. 1, No. 1-2, (January-April 2003), 111-141. 
Pollak, Robert A., "Samuelson's 'Dr. Jekyll and Mrs. Jekyll' Problem: A Difficulty in the Concept of the Consumer." In M. Szenberg, L. Ramrattan, and A. Gottesman, eds., Samuelsonian Economics and the Twenty-First Century, Oxford: Oxford University Press, 2006, 116-126.

Pollak, Robert A. "Bargaining Around the Hearth," Yale Law Journal Pocket Part 116 (April 16, 2007) 414 http://thepocketpart.org/4/16/pollak.html NBER Working Paper 13142, May 2007.

Pollak, Robert A., "Allocating Household Time: Does Efficiency Imply Specialization?" April 2012.

Pollak, Robert A., and Michael L. Wachter, "The Relevance of the Household Production Function and Its Implications for the Allocation of Time," Journal of Political Economy, Vol. 83, No. 2, (April 1975), 255-277.

Reid, Margaret G., Economics of Household Production, New York: John Wiley \& Sons Inc., 1934.

Samuelson, Paul A., "Social Indifference Curves," Quarterly Journal of Economics, Vol. 70, No. 1, (February 1956), 1-22.

Williamson, Oliver E., "The Theory of the Firm as Governance Structure: From Choice to Contract," Journal of Economic Perspectives, Vol. 16, No. 3, (September 2002), 171195. 